\title{
El escritor polaco Jerzy Stefan Stawiński en su versión rusa: reflexiones sobre la importancia del estilo en la traducción
}

\author{
Mabel Greta Velis Blinova \\ Universidad Complutense de Madrid \\ mgvelis@pdi.ucm.es
}

Recibido: 7 de enero de 2014

Aceptado: 10 de febrero de 2014

\begin{abstract}
RESUMEN
El presente artículo analiza las particularidades del estilo literario y su preservación en la traducción tomando como ejemplo una de las novelas del destacado escritor polaco Jerzy Stefan Stawiński (1921-2010). Se trata del estudio de las dominantes estilísticas y de la adecuada selección de equivalentes lingüísticos en la traducción a la lengua rusa del original polaco teniendo en cuenta algunos aspectos pragmáticos. El trabajo también expone reflexiones sobre las posibilidades de la lengua española a la hora de transmitir el estilo de este autor.
\end{abstract}

Palabras clave: Estilo literario, traducción, aspectos lingüísticos y pragmáticos, lengua rusa, lengua polaca, lengua española.

The Polish writer Jerzy Stefan Stawiński in the Russian version: reflections on the importance of style in translation

\begin{abstract}
The present article analyzes the peculiarities of literary style and its preservation in translation taking as an example one of the novels of the outstanding Polish writer Jerzy Stefan Stawiński (1921-2010). In this writer, the issue is the study of the domineering stylistic units and of the suitable selection of linguistic equivalent in the translation to Russian from the original Polish bearing in mind some pragmatic aspects. The work also reflects on the possibilities of the Spanish language in transmitting the style of this author.
\end{abstract}

Keywords: Literary style, translation, linguistic and pragmatic aspects, Russian language, Polish language, Spanish language.

Sumario: 1. Introducción. 2. El argumento como dominante estilística. 3. El papel de la sintaxis y de la composición del lenguaje literario. 


\section{Introducción}

La calidad literaria de la traducción es fundamental en la recepción extranjera de una obra: la responsabilidad del traductor se halla en despertar el mismo interés y sensaciones en el lector ajeno a la comunidad lingüística y cultural de donde proviene el texto original. Además de transmitir el mensaje correcto y el argumento que guarda la obra, ante el traductor se presentan otros retos difíciles de afrontar. Se trata de ser fiel al estilo de un escritor, algo que a menudo implica la lectura de otras obras del mismo autor, el conocimiento de su idiosincrasia, de su experiencia vital. El estilo es el camino para conquistar el corazón del lector, esa categoría aparentemente abstracta que está en cada palabra, en cada línea de un gran libro, esa perfecta compenetración entre forma y contenido capaz de revelar las inquietudes, la personalidad, la mentalidad de un escritor, las particularidades de la época y de la generación a la que perteneció.

Una de las claves del éxito que tuvo el escritor polaco Jerzy Stefan Stawiński (1921-2010) en la Unión Soviética allá por los años 1960-1970 es precisamente su estilo, que respondió a las necesidades y expectativas de un público lector muy exigente. En el presente trabajo analizaremos algunos de los recursos y procedimientos lingüísticos y pragmáticos en la traducción de su obra a la lengua rusa que han hecho posible la transmisión del original estilo del escritor. Asimismo estudiaremos las posibilidades lingüísticas y gramaticales de la lengua española para trasladar esa manera sutil y aparentemente sencilla de abordar una realidad que muchos autores han tratado desde el dramatismo y la desesperación.

La obra de Stawiński rinde homenaje a su generación, a aquellos jóvenes polacos que entregaron sus vidas en la lucha por la independencia de su país durante la Segunda Guerra Mundial. Es éste un mundo de pérdidas, de esperanzas e ilusiones arrebatadas, de sacrificio desinteresado de quienes aún en condiciones extremas lo que pretendían no era, evocando palabras de otro magnífico escritor, Curzio Malaparte, salvar la piel sino el alma. Se trata de una experiencia trágica, vivida por el propio escritor cuya juventud transcurrió en las trincheras y barricadas, al servicio de la Resistencia, quien participó en la Campaña de Septiembre ${ }^{1}$ y en el Levantamiento de Varsovia, quien estuvo en las filas del Ejército de Anders². Aún así, el autor « не прибегает к мрачным тонам и краскам, и хотя картина, которую он рисует $[. .$.$] печальна и драматична, печаль здесь светла, а от драматизма не$

${ }^{1}$ La resistencia polaca ante la invasión alemana el 1 de septiembre de 1939 que desencadenó la declaración de la guerra por parte de Gran Bretaña y Francia a Alemania. Ante la enorme superioridad de la maquinaria alemana y la falta de la prometida ayuda francesa e inglesa además de la entrada de las tropas soviéticas en el país el 17 de septiembre, Polonia volvía a ser ocupada. El acuerdo entre Alemania y la Unión Soviética del 28 de septiembre dividía a Polonia en dos partes a lo largo de los ríos Narwa, Bug y San.

${ }^{2}$ El general polaco Władysław Anders (1892-1970) destacó por su participación en la Campaña de Italia, y en la Campaña en África del Norte durante la Segunda Guerra Mundial. La contribución de las tropas polacas bajo el mando de Anders en la victoria de la sangrienta Batalla de Montecassino (1944) por la toma de Roma fue muy relevante. Anders es considerado uno de los símbolos de la Resistencia polaca y de la lucha por la independencia del país. 
веет горечью»³ (Ермонский 1981: 4). Como el mismo Stawiński reconoce en más de una entrevista, como así lo refleja su obra, ésta fue la etapa más trágica y al mismo tiempo la más memorable y auténtica en la vida del escritor, con ella se fueron los sentimientos más sinceros, la proeza y la entrega desinteresada.

El presente trabajo se centra en la novela Młodego warszawiaka zapiski z urod$z i n^{4}$, según muchos críticos polacos y soviéticos, el libro donde Stawiński se manifiesta en todo su esplendor y talento literario, la última gran palabra del escritor en lo que al tema de la guerra se refiere. Destacaremos algunos de los fragmentos que mejor revelan las particularidades del estilo del escritor acompañados de su correspondiente traducción a la lengua rusa y española ${ }^{5}$.

\section{El argumento como dominante estilística}

Las dominantes estilísticas que revela el siguiente pasaje son la naturaleza argumentativa y el psicologismo, dos de las tres posibilidades, junto con la descripción, de representar la imagen de la realidad, del mundo en una obra literaria. El argumento y el psicologismo prevalecen sobre una descripción que se reduce a lo esencial:

A jednak nie wytrzymałem napięcia: $\mathrm{w}$ ostatniej chwili uskoczyłem w załom furtki, chowając za siebie jasne plamy kwiatów. Stałem nieruchomo i tchórzliwie. Samochód przejechał. Teraz biegłem szybko na palcach dla zmniejszenia hałasu. Znowu byłem tchórzliwym zającem w zbożu, otoczonym przez myśliwych: jeżeli wystawię nos, zaraz padnie strzał. Ta sytuacja sprzeczała się z całą ideologią szlachetnej walki z odsłoniętą przyłbicą, piersią w pierś. By zachować godność, zmusiłem nogi do spokojnego marszu.

Dopiero o parę metrów od Madalińskiego usłyszałem niemiecką rozmowę i gardłowe śmiechy. Nie rzuciłem się do ucieczki, chociaż przez zajęczy grzbiet przeszedł mi paraliżujący skurcz strachu, a w skroniach załopotało przyśpieszone tętno.

Wystawiłem przed siebie kwiaty i szedłem jak człowiek beztroski i nieco pijany. Zza rogu wytoczyło się w Aleję pięciu żołnierzy. Rechotali po każdym zdaniu opowiadacza dowcipu. Pierwszy, który mnie dostrzegł, odruchowo położył rękę na kaburze pistoletu, bo ostrzegano ich nieustannie przed polskimi bandytami po nocy, ale zaraz uspokoił go mój swobodny krok i kwiaty. Wyglądałem na amanta idącego w zaloty. Spojrzeli na mnie przelotnie, ale żaden nie zagadał; dopiero gdy ich minąłem, padło groźne pytanie: „A co on tu robi po nocy, ten Polak?”, i zaraz przyszła leniwa odpowiedź: „Daj spokój, Hermann, to sprawa policji!” Tak się nie zachowywali wcześniej, kiedy szli do przodu: w roku 1940 uciekałem po stolikach, przez kuchnię kawiarni aż do piwnicy, a z tyłu pędziło dwóch lotników z

\footnotetext{
3 "No recurre a tonos y colores sombríos, y a pesar de que la imagen que el escritor esboza [...] es triste y dramática, la tristeza aquí es traslúcida y el dramatismo libre de amargura".

4 El título de la novela está traducido al ruso como Записки молодого варшавянина. En español se podría traducir de la siguiente forma: Apuntes de un joven varsoviano en el día de su cumpleaños.

${ }^{5}$ La novela no está publicada en español, motivo por el cual nos centramos ante todo en el análisis de la traducción oficial al ruso.
} 
pistoletami w ręku, by mnie zmasakrować czy zastrzelić tylko dlatego, że im się nie podobało moje spojrzenie. Długo biegali po podwórzu i ulicy; przyglądałem się ich butom przez piwniczne okienko i wtedy dowiedziałem się po raz pierwszy, czego tych pilotów uczyła o Polakach oficjalna propaganda. Nic dziwnego, że nas z taką lubością masakrowali bombami.

W ten sposób, nie nagabywany dzięki niepowodzeniom na frontach, dotarłem bez przeszkód do domu Teresy. Nie mogło być mowy o budzeniu dozorcy, zaszedłem od tyłu, przeskoczyłem przez wysoki płot i dotarłem do tylnych drzwi, zawsze otwartych. Wbiegłem po schodach i zastukałem cicho umówionym kodem. Teresa otworzyła, przestraszona. W niebieskiej koszuli nocnej wyglądała jak w balowej sukni. Wyciągnąłem dalie. (Stawiński 2006: 101-102).

И все же я не выдержал напряжения: в последнюю минуту отпрянул в нишу подворотни и, трусливо прижавшись к запертым воротам, пряча за спиной светлые пятна цветов, стоял не двигаясь, пока машина не проехала. А потом быстро побежал на цыпочках, чтоб производить поменьше шума. Я снова был трусливым зайцем во ржи, окруженным охотниками, — стоило высунуть нос, как тут же прогремели бы выстрелы. Эта ситуация противоречила моему идеалу рыцарской битвы лицом к лицу, с открытым забралом. Спасая свое достоинство, я заставил себя перейти на спокойный шаг.

В нескольких метрах от улицы Мадалинского я услышал немецкую речь и гортанный смех. Я не бросился наутек, хотя вдоль моей заячьей спины прокатилась парализующая судорога страха, а в висках застучал взбесившийся пульс. Выставив вперед цветы, я продолжал идти как человек беззаботный и чуть под хмельком. Из-за угла на Аллею выползло пятеро солдат. Один из них рассказывал анекдот, остальные гоготали после каждой фразы. Солдат, заметивший меня первым, мгновенно положил руку на кобуру пистолета - ведь они постоянно боялись, что ночью на них могут напасть польские бандиты, - но тут же успокоился, увидев, что я продолжаю мирно шествовать, помахивая цветами; любовник, идущий на свидание. Остальные только внимательно оглядели меня, но не окликнули. Лишь когда я миновал их, позади послышался грозный вопрос по-немецки: «А что он тут делает ночью, этот поляк?» и сразу же ленивый ответ: «Брось, Герман, пусть этим занимается полиция!» Раньше, когда они перли вперед, они вели себя иначе: в 1940 году я удирал, прыгая по столикам кафе, до самой кухни, где спрятался в подвале, а за мной с пистолетами в руках гнались двое летчиков, пытавшихся изуродовать или пристрелить меня только потому, что им не понравился мой взгляд. Они долго бегали по двору и по улице, а я рассматривал из подвала их сапоги. Тогда я впервые услышал, какую чушь о Польше и поляках вбивала в головы своих граждан официальная немецкая пропаганда. Не было ничего удивительного, что немецкие летчики с таким удовольствием бомбили нас.

Я беспрепятственно добрался до дома Терезы. Будить привратника в моем положении было бы сверхглупостью, поэтому я обошел дом, перелез через высокий забор и пробрался к черному входу, который всегда был открыт. Взбежав по лестнице, я тихо постучал в дверь условным знаком. Открыла перепуганная Тереза. В голубой ночной рубашке она выглядела как в бальном платье. Я протянул ей георгины. (Ставинский 1981: 454-455) 
Sin embargo, no soporté la tensión: en el último minuto retrocedí al nicho del renvalso, escondiendo detrás de la espalda una clara mancha de flores. Así permanecí sin moverme y asustado. El coche pasó de largo. En seguida corrí rápidamente de puntillas para causar el menor ruido posible. Una vez más, me había convertido en una liebre cobarde en un centeno rodeada de cazadores, bastaba con asomar la nariz para que resonaran los disparos. Esta situación era contraria a la idea de la lucha noble, frente a frente, a cara descubierta. Poniendo a salvo mi dignidad me ordené adoptar un paso tranquilo. A escasos metros de la calle Madalinski oí voces en alemán y una risa gutural. Me quedé quieto a pesar del paralizante calambre de miedo que recorría mi espalda de liebre y a pesar del acelerado pulso en las sienes.

Exhibí las flores y caminé como un hombre despreocupado y algo borracho. De la esquina a la avenida salieron cinco soldados. Se reían a carcajadas después de cada frase del chiste que uno de ellos venía contando. El primero en verme puso inmediatamente la mano en la pistolera, no paraban de prevenirles ante los asaltos de los bandidos polacos por las noches, aún así, en seguida se calmó al ver mi paso tranquilo y las flores. Parecía un amante de camino a una cita. Me lanzaron una mirada rápida pero ninguno dijo nada; tan solo cuando los dejé atrás, resonó la pregunta amenazadora: “¿Qué hace aquí, por la noche el polaco este?”, y enseguida vino la vaga respuesta: “¡Déjalo, Hermann, es cosa de la policía!” Antes no se comportaban así, cuando llevaban la delantera: en el año 1940 tenía que huir saltando de mesa en mesa, atravesando la cocina de la cafetería hasta llegar al sótano, mientras dos aviadores me perseguían a toda velocidad con las pistolas en la mano para mutilarme o pegarme un tiro por el mero hecho de que no les había gustado mi mirada. Estuvieron corriendo por el patio y por la calle durante un largo rato; yo me dediqué a observar sus botas a través de la ventana del sótano y fue cuando me enteré de las cosas que la propaganda oficial les enseñaba sobre los polacos. No es de extrañar que se dedicaran a masacrarnos con tanta aplicación lanzando bombas.

Así, sin ser molestado gracias al fracaso en el frente, conseguí llegar a la casa de Teresa sin impedimento. Despertar al conserje en mi situación era una gran bobada, di la vuelta a la casa, escalé una tapia bien alta y accedí con cautela a la puerta trasera que siempre estaba abierta. Subí corriendo las escaleras y llamé a la puerta sin hacer ruido utilizando la contraseña. Me abrió una Teresa asustada. Con su camisón azul celeste parecía llevar un vestido de baile. Le entregué las dalias. ${ }^{6}$

El principal objetivo del autor, tanto en este fragmento en particular como en toda su producción literaria sobre la guerra, es transmitir su experiencia, la de Polonia y la de su generación en aquellos años entre 1939 y 1944. Stawiński desea hacer llegar lo vivido, lo sufrido a un lector que probablemente desconoce detalles importantes pero a menudo postergados en los libros de historia. Y no solamente se trata de trasladar una situación y unos hechos sino también el estado espiritual de los personajes. La descripción es mínima en tanto en cuanto el objetivo no es introducir al lector en la época, en el mundo de las cosas y de la realidad exterior; lo importante

${ }^{6}$ La traducción al español de los fragmentos analizados es de la autora del artículo. 
son aquí los sentimientos, el mundo interior de los personajes en el contexto de la guerra, y la descripción, cuando aparece, se somete a la función de manifestar lo vivido. Descubrimos el carácter argumentativo en la secuencia de imágenes, de situaciones, en la dinámica de los acontecimientos con una importante carga semántica. Cada gesto, cada movimiento, cada palabra tienen un significado, son detalles - símbolo que nos abren el mundo interior de los personajes y la verdad de los acontecimientos. El psicologismo se alcanza de forma indirecta aunque en alguna ocasión intervienen recursos propios del psicologismo interior, como son los recuerdos y la imaginación. La originalidad se halla en el vínculo inseparable entre la acción y el mundo interior de los personajes dando lugar a un estilo ligero, dinámico a la vez que intenso.

En el texto original, el carácter argumentativo, el ritmo ágil y dinámico es producto, entre otras cosas, del empleo de un gran número de verbos y de una construcción sintáctica concisa. El espectro de oraciones es muy amplio, encontramos oraciones simples, oraciones compuestas de todo tipo, por coordinación y subordinación, pero todas ellas con una estructura lacónica y con una secuencia lógica.

La traducción al ruso logra conservar el estilo del escritor pero mediante recursos lingüísticos algo distintos. Si bien un escritor no necesariamente se detiene ante la selección de unas u otras categorías gramaticales, estructuras sintácticas etc. sino que lleva a cabo el cometido haciendo uso de su talento literario y creatividad, la labor del traductor sí precisa de un previo análisis con el fin de hacer llegar no solamente la temática, la problemática de una obra literaria sino el estilo empleando aquellas formas lingüísticas del idioma al que se traduce que sean las más adecuadas atendiendo a las particularidades de cada lengua. Así, en la versión rusa además del verbo se utiliza el participio adverbial anterior y contemporáneo que en varias ocasiones sustituye al verbo del original sin alterar el tempo propio del fragmento analizado y de toda la obra. La traducción literal en algunos casos sería incorrecta como, por ejemplo, en la siguiente frase:

Tak się nie zachowywali wcześniej, kiedy szli do przodu: w roku 1940 uciekałem po stolikach, przez kuchnię kawiarni aż do piwnicy [...].

Раньше, когда они перли вперед, они вели себя иначе: в 1940 году я удирал по столикам кафе, до самой кухни [...].

En esta situación el traductor introduce un participio adverbial contemporáneo para transmitir la misma idea y preservando el estilo que hallamos en el texto polaco pero siendo coherente con las exigencias de la lengua rusa:

Раньше, когда они перли вперед, они вели себя иначе: в 1940 году я удирал, прыгая по столикам кафе, до самой кухни [...].

En otros casos la traducción literal de los verbos requeriría la utilización del pronombre personal en su función de sujeto que en la lengua rusa debe acompañar al verbo cuando éste aparece en tiempo Pretérito. Esta condición puede entorpecer la 
secuencia fluida que contribuye a ese estilo ligero, dinámico y argumentativo del escritor. En la lengua polaca no se presenta tal problema ya que la desinencia del verbo tanto en tiempo Presente como Pretérito y Futuro indica la persona en la oración. En los ejemplos de traducción literal que veremos a continuación el pronombre personal no solamente agravaría el estilo sino que rompería la estética del fragmento al tratarse de una repetición. Nuevamente el participio adverbial resulta ser en la traducción oficial una solución en este contexto evitando la repetición y la necesidad de introducir el pronombre personal junto al verbo.

Nie rzucitem się do ucieczki, chociaż przez zajęczy grzbiet przeszedł mi paraliżujący skurcz strachu, a w skroniach załopotało przyśpieszone tętno. Wystawitem przed siebie kwiaty i szedłem jak człowiek beztroski i nieco pijany.

Я не бросился наутек, хотя вдоль моей заячьей спины прокатилась парализующая судорога страха, а в висках застучал взбесившийся пульс. $Я$ выставил вперед цветы и продолжал идти как человек беззаботный и чуть под хмельком.

A jednak nie wytrzymatem napięcia: w ostatniej chwili uskoczyłem w załom furtki, chowając za siebie jasne plamy kwiatów. Stałem nieruchomo i tchórzliwie.

И все же $я$ не выдержал напряжения: в последнюю минуту отпрянул в нишу подворотни, пряча за спиной светлые пятна цветов. Я стоял неподвижно и трусливо.

Al mismo tiempo, el participio adverbial sustituye en el texto algunos verbos cuya traducción literal al ruso y en el contexto determinado de la frase no sería incorrecta. Se trata de las frases donde el verbo polaco no está en tiempo Pretérito, sino en su forma impersonal de infinitivo y no precisa ser acompañado de un pronombre personal al existir sujeto en la oración expresado mediante sustantivo. Habiendo podido preservar las categorías gramaticales del texto polaco, el traductor opta en este caso por seguir utilizando el participio adverbial, decisión bastante acertada si es que se pretende dar continuidad estilística y mantener la forma adoptada desde un principio. Cabe señalar que los giros de participio adverbial en la lengua rusa constituyen un importante recurso de cohesión lógica en el texto, pueden transmitir una acción anterior y a la vez posterior a otra, proporcionándole a la narración un ritmo más dinámico en la secuencia de imágenes y acontecimientos.

En cuanto a la traducción al español, el carácter argumentativo se transmitiría mejor mediante el uso del verbo, al igual que ocurre en el original, en ocasiones mediante un giro de infinitivo. El participio adverbial anterior polaco y ruso equivale al gerundio compuesto en español, una forma larga y pesada que ya desde el punto de vista estructural supondría un inconveniente para transmitir el estilo enérgico y veloz de la obra. El participio adverbial anterior ruso, en cambio, suele ser más breve en su construcción. El uso inadecuado de las formas lingüísticas y gramaticales frenaría la acción durante el trayecto para llegar a la casa de Teresa que lleva a cabo el protagonista. He aquí la importancia de la forma en una obra litera- 
ria, su papel en la construcción del propio contenido. El verbo en el tiempo Pretérito Indefinido sería la mejor opción para transmitir en español el carácter argumentativo y vivo del texto, la sucesión de imágenes y el cambio de escenario, efecto que en el original se alcanza mediante los numerosos verbos en aspecto perfectivo, principio básico y fundamental en el sistema de verbos polacos y también rusos.

A modo de comparación, un buen ejemplo en la literatura española donde descubrimos un estilo parecido al de Stawińksi es la obra del magnífico escritor contemporáneo Antonio Muñoz Molina. Su manera de abordar los acontecimientos, de hacernos llegar los sentimientos de los personajes es también sutil, ágil y con esa dosis de melancolía que tanto caracteriza la literatura de ambos. El fragmento que se ofrece a continuación ilustra la presteza con la que el autor español expone los hechos, la secuencia casi cinematográfica de unos gestos y movimientos fáciles de visualizar:

Pero el grito, que lo había alertado, se unió al sonido del primer disparo para quebrar el instante inmóvil y despertarlo del letargo, del fatalismo de morir. Su mano derecha, al hacer el gesto de proteger la cara, había golpeado el brazo rígido que sostenía la pistola, y el disparo que una fracción de segundo antes le habría destrozado la cabeza sin que él llegara a enterarse de que iba a morir rompió con un cataclismo de cristales el escaparate de una tienda. Echó a correr, pero se dio cuenta de que no le daría tiempo a llegar a la esquina y se tiró al suelo y rodó buscando refugio entre los coches aparcados, protegiéndose la cabeza con los dos brazos cruzados sobre la cara. Contó uno por uno los tres disparos que siguieron, asombrado de no sentir dolor, de estar vivo aún para seguir escuchando y arrastrándose, sin alcanzar nunca el filo de la acera donde estaban los coches, para oler a pólvora y ver sobre el pavimento de la acera unas zapatillas blancas salpicadas de sangre. "Ahora se ha acercado más para rematarme, pero ese disparo ya no lo escucharé", pensó con una clarividencia parecida a la de esos brotes fugaces de racionalidad que surgen a veces en medio de un sueño. Quiso alzar la cara del suelo para ver de nuevo la de quien iba a matarle, pero no tuvo fuerzas, se quedó respirando con la boca abierta contra la losa que quemaba y escuchó un ruido metálico y familiar, el del gatillo de una pistola encasquillada, y luego un roce de pisadas que se iban. (Muñoz Molina 2006: 394-395)

El verbo en tiempo Pretérito de Indefinido marca el ritmo acelerado a lo largo del fragmento, es la categoría que constituye la unión morfológica del texto, la cohesión gramatical, acorde con la naturaleza argumentativa del mismo.

\section{El papel estilístico de la sintaxis y de la composición del lenguaje literario}

El argumento como dominante estilística se revela por medio de otros recursos que tienen que ver con otra de las dominantes estilísticas que existen, y en este caso al servicio del carácter argumentativo. Se trata de la cualidad nominativa del texto en la esfera de la lengua literaria que se desprende del uso preciso, exacto de la palabra, de una construcción sintáctica sencilla o relativamente sencilla, de la realidad 
retratada como principal objetivo frente a un estilo retórico donde abundan las figuras sintácticas, el empleo de las palabras en su sentido figurado, donde la riqueza se halla en un gran número de recursos léxicos. Tanto el fragmento analizado como todo el texto de la obra es desde el punto de vista estilístico nominativo: el lenguaje y la sintaxis son lacónicos, no sobra ni una sola palabra, cada una se emplea con acierto y precisión, los epítetos son frecuentes, el autor no recurre al excesivo uso de hipérboles, ni metáforas. Con un mínimo imprescindible de recursos y ligeras pinceladas se logra un extraordinario efecto, el mismo que debe lograr el traductor mediante la búsqueda de aquellos equivalentes capaces de transmitir la misma fuerza expresiva contenida en el original. La carencia ornamental no necesariamente facilita el trabajo del traductor quien debe encontrar y cuidar esos otros recursos que en este caso contribuyen no solamente a la creación de un estilo ligero en su percepción sino tremendamente convincente.

Merece especial atención el tejido sintáctico, del cual se ha dicho en pasajes anteriores que es rico y variado: el autor construye frases compuestas, oraciones subordinadas consecutivas, finales, causales, de tiempo, oraciones coordinadas copulativas, adversativas etc., pero la gran mayoría de ellas son breves y lacónicas. La relativa sencillez se halla también en el protagonismo de la oración simple, en ocasiones únicamente compuesta de sujeto y predicado. El carácter lacónico de las oraciones compuestas se consigue mediante un cuidadoso uso de los signos de puntuación con un papel importante a la hora de marcar el ritmo del texto. Otro elemento importante con gran capacidad de síntesis en el interior de la frase es el participio adjetival y el giro de participio adjetival que reúne cualidades del verbo y del adjetivo y sustituye la frase subordinada de relativo. Se trata de un recurso capaz de aportar bastante contenido e información en una sola o en pocas palabras. Junto al participio adjetival, tanto activo como pasivo, el autor incorpora otra construcción específica dentro del participio adjetival activo, la forma impersonal acabada en - o que debido a su carácter neutro e impersonal no precisa ir acompañada del sujeto. En el texto predomina la cohesión sintáctica en cadena con algunas descripciones breves, ya sea para narrar la secuencia de movimientos del protagonista como de otros personajes y objetos involucrados en la acción.

La sintaxis que descubrimos en la traducción a la lengua rusa logra transmitir el ritmo fluido y veloz del original. Aquí la cohesión sintáctica también es en cadena, la oración simple también cobra protagonismo y en el caso de las estructuras compuestas, los signos de puntuación, en su mayoría, coinciden con el mismo objetivo de síntesis y organización. El participio adjetival es también frecuente, logrando el mismo efecto en el interior de la frase, incluso podríamos decir que su uso es mayor en la versión rusa, ya que se emplea allí donde el escritor se sirve de la oración subordinada. La forma impersonal acabada en - o del participio adjetival, a su vez, sufre un cambio de categoría gramatical en la traducción. A pesar de que dicha forma existe en ambas lenguas, en ruso se reserva para oraciones sin complemento directo siendo la traducción literal una opción incorrecta en el contexto sintáctico del presente texto. Su equivalente en ruso sería en este caso la forma del verbo en tercera persona del plural de tiempo Pretérito o una construcción pasiva. El traductor, sin embargo, encuentra otra solución: la elección de un verbo de semántica dife- 
rente a la original en su función de predicado con el correspondiente sujeto:

[...] odruchowo położył rękę na kaburze pistoletu, bo ostrzegano ich nieustannie przed polskimi bandytami po nocy $[\ldots]$

[...] мгновенно положил руку на кобуру пистолета — ведь они постоянно боялись, что ночью на них могут напасть польские бандиты [...]

Así pues, el traductor logra ajustarse a la sintaxis original mediante recursos iguales o similares sin violar el contenido, transmitiendo el mismo ritmo y la cadencia marcada como una de las particularidades más destacadas en el estilo del escritor que, como hemos señalado, no solamente facilita la lectura sino que da lugar a un discurso muy convincente. En el texto no hay sentencias, no hay didactismo, ni lecciones de moral pero sí un manejo equilibrado y mesurado de la lengua. No hay nada que pueda distraer al lector de unos hechos concretos y precisos. Incluso en el caso en que se hallan digresiones del autor a lo largo de la obra o episodios intercalados, casi todos sobre los juegos políticos y el destino de su generación en la guerra, se producen en boca de los personajes y mediante el reflejo de una realidad, de una situación concreta. Sin alusiones o sentencias directas sobre el papel de las potencias y del propio gobierno polaco en el exilio durante la contienda se revelan grandes verdades. El mismo efecto es posible en la traducción al español gracias a técnicas sintácticas muy cercanas al original.

Además de la sintaxis, otro recurso importante que participa del estilo en la obra es la composición del lenguaje literario, concretamente el cambio de las formas narrativas. La dificultad que se presenta ante el traductor consiste en transmitir el cambio sutil pero perceptible en el discurso de Stawiński, los distintos tonos y maneras que atraviesan toda la novela como una constante estilística. La ironía en la obra sucede pasajes líricos o la manera dramática que a su vez da paso a un tono tranquilo y sosegado en función del tema pero también de la actitud, de la experiencia de los personajes contribuyendo a la construcción del propio contenido. Los fragmentos que presentamos a continuación son la muestra de la riqueza estilística de Stawiński desde el punto de vista del cambio de las formas narrativas que sin duda es una de las tareas más delicadas para el traductor.

Pamiętam dobrze ten dzień. W maju tego roku zdałem maturę i zgodnie z wprowadzonymi wtedy przepisami szykowałem się do rocznej służby wojskowej. Przybyłem nocnym pociągiem do Zakopanego, bo ojciec chciał mnie tu przedstawić swojej żonie. W dziedzinie małżeństwa wyprzedzał swą epokę: zamiast mieć jedną ślubną żonę i wiele kochanek jak to było zwyczajem w jego sferze, postanowił na wzór amerykański mieć wiele żon i ani jednej kochanki, dysponował bowiem czasem i pieniędzmi. Każdy rozwód i następny ślub okupował zmianą wyznania, jako że nie było wtedy innego sposobu; z katolika przemienił się w ewangelika reformowanego, później przeniósł się na łono prawosławia, a tę czwartą żonę poślubił w Wilnie, zwrócony w stronę Mekki, wybijając pokłony, gdyż tam był meczet. Tym, co go nie znali, wmawiał, że w przeróżnych formach monoteistycznego kultu szuka najdoskonalszego sposobu łączności z Istotą Najwyższą, wznosząc się ponad tradycje i przesądy naszego katolickiego kraju; ja 
dobrze wiedziałem, że chodzi o babę, i nawet się cieszyłem, że ojciec już kroczy w stronę starości. Pochodziłem z pierwszego, katolickiego małżeństwa i mieszkałem razem z matką, nauczycielką historii [...].

W Zakopanem wynajął mi pokój wraz z utrzymaniem w pensjonacie „Orlik” za siedem złotych dziennie, bo chciał uczcić za jednym zamachem i dzień moich urodzin, i moją maturę, i odejście do wojska, gdyż kartę powołania miałem już w kieszeni. Jeszcze w maju pochyliliśmy się z ojcem nad mapą podchorążówek, żeby znaleźć dla mnie tę najbardziej znośną i najbliższą Warszawy. W samej Warszawie działała podówczas tylko Szkoła Podchorążych Sanitarnych, i to zawodowa. Nigdy nie chciałem zostać lekarzem, a tym bardziej wojskowym: służbę w wojsku uważałem za obowiązek i przywilej, cieszyłem się już na myśl o mundurze, ale miał to być w moim życiu tylko krótki, roczny epizod. (Stawiński 2006: 7)

Aquí, al igual que en otros pasajes de la novela, la ironía con la que el narradorprotagonista aborda las aventuras matrimoniales de su padre da paso a un discurso sereno sobre su futuro en el ejército donde el joven iba a ingresar con gran ilusión y orgullo. Un tema cotidiano sucede a otro bajo registros estilísticos distintos cuya transformación se produce suave y sutilmente gracias entre otras cosas a una ironía ligera que no roza el sarcasmo ni la sátira, no pretende ridiculizar. Es una actitud ante la realidad, una visión del mundo, una forma de sobrellevar los hechos, trátese de una temática cotidiana, política o existencial. La traducción, en este caso, de no tener en cuenta detalles tan sustanciales como éste, de no preservar el tono volátil de la risa inteligente, puede resultar brusca, tosca y por lo tanto cambiar el efecto que provoca el original. Veamos si la traducción al ruso logra transmitir el tono irónico del original:

Я хорошо помню этот день. В мае я получил аттестат зрелости и, согласно недавно введенному закону, должен был вскоре отбыть годичную воинскую службу. День этот я провел в Закопане, куда отец вызвал меня, чтобы представить своей четвертой жене. В вопросах супружеской жизни отец явно опережал эпоху: вместо того чтобы иметь, как было принято в его кругу, одну законную жену и много любовниц, он, располагая временем и средствами, предпочел жить на американский лад, то есть иметь много жен и ни одной любовницы. За каждый развод и последующий брак ему приходилось платить сменой вероисповедания, поскольку иного выхода тогда не было. Так из католика он стал лютеранином, затем некоторое время был православным, а с этой, четвертой, женой бракосочетался в Вильно, где была мечеть, и теперь молился, обратя лик свой в сторону Мекки.

Людей малознакомых он старался убедить, будто, отвергая традиции и предрассудки нашей католической страны, пытается найти в разных формах монотеистического культа наиболее совершенный способ общения с всевышним. Но я-то хорошо знал, что все дело был попросту в этих его чертовых бабах, и даже радовался, что отец начинал стариться. Законный сын от его первого, католического брака, я жил с матерью, учительницей истории, и терпеть не мог отцовских жен [...].

Прибыв в Закопане ночным поездом, я отправился прямо в частный отель «Орлик», где отец снял для меня довольно дорогую комнату с пансионом, намереваясь таким образом отметить сразу и день моего рождения, и 
аттестат зрелости, и уход в армию, поскольку призывная повестка уже лежала у меня в кармане. Мы с отцом еще в мае, склонившись над картой, изучили расположение военных училищ, чтобы выбрать наиболее сносное из них и менее отдаленное от Варшавы. В самой Варшаве в то время находилась только санитарная школа подхорунжих - и то для будущих кадровых военврачей. Мне же никогда не хотелось стать врачом, тем паче военным; службу в армии я считал долгом и привилегией и радовался, что скоро надену мундир, однако я считал, что в моей жизни это должен быть лишь краткий эпизод. (Ставинский 1981: 353-354)

El tema sobre la inestabilidad en la vida personal de un padre entregado a sí mismo, narrado por el hijo-protagonista, podría ser abordado desde un tono serio, dramático o sarcástico. El traductor, siguiendo los pasos del autor, debe mantener la misma actitud hasta cierto punto distante y no cruzar la frontera, fácilmente franqueable, que conduciría a la burla, a la amargura, a un tono agresivo. Al igual que en el texto polaco, la ironía sutil se consigue en la traducción mediante un léxico alegórico. Un lenguaje más directo en este contexto crearía un tono más despiadado e incompatible con la idea que desea transmitir el autor: a pesar de los escarceos amorosos del padre, el hijo le tiene afecto, su figura es entrañable y conmovedora. Vemos como el traductor cumple con su papel de lector profesional, su postura es pragmáticamente neutral en el intento de transmitir con exactitud el potencial comunicativo del texto. La ironía es empleada en la versión rusa en su medida adecuada independientemente de la respuesta afectiva que podría ocasionar en el traductor el propio contenido.

Los cambios de las formas de narración se dan en la obra entre párrafos, entre unidades sintácticas mayores, pero también en el interior de un párrafo, algo posible precisamente gracias al equilibrio de cada una de esas formas: la ironía de Stawiński es ligera, el dramatismo no es desgarrador, el lirismo no es excesivamente sentimental. La ironía del siguiente fragmento se ve espontáneamente interrumpida por un comentario de lo más serio, algo que se percibe perfectamente en la traducción al ruso:

Propozycja była na tyle interesująca, że zaraz wyjechali do Juraty, a dziewczyna nie wróciła już do stróżówki; w ciągu sześciu miesięcy stary zakochał się w ciele aż po łysinę i przeszedł na mahometanizm, by uzyskać rozwód z trzecią żoną rozhisteryzowaną aktorką Marysią. Teraz moge zrozumieć te słabości; wtedy, w dniu moich siedemnastych urodzin, patrzyłem na Jadźkę z nienawiścią. Ojciec doskonale to wyczuwał i nie starał się łagodzić; usprawiedliwiał, widać, tę wrogość. O ile go zrozumiałem, posądzał mnie o podwójną zazdrość: o niego i o nią. (Stawiński 2006: 9)

Предложение оказалось настолько интересным, что они в тот же день выехали на фешенебельный курорт Юрату, и девушка вообще уже больше не вернулась в дворницкую; прожив с ней шесть месяцев, мой старик так одурел от прелестей ее тела, что принял магометанство, чтобы получить развод со своей третьей женой, Марысей - взбалмошной, истеричной актрисой. Tеперь-то я могу понять многие слабости отща, но тогда, в мой семнадцатый день 
рождения, я смотрел на Ядю с ненавистью. Отец отлично видел это и не старался задобрить меня, вероятно, моя враждебность казалась ему естественной, поскольку он считал, по-видимому, что я ревную, да еще не только его, но и ее. (Ставинский 1981: 355)

Jadzia es un excelente ejemplo de la importancia que pueden tener las formas narrativas a la hora de mostrar el cambio de perspectiva para con un personaje en función del momento y de las circunstancias:

- Cholerycznie lubię, jak pięknie grają i śpiewają - powiedziała Jadzia. Znajdowała się na pierwszym etapie zachwycenia wszystkim, co ją spotykało, i nie spuszczała oka z ojca-czarodzieja,czekając na coraz to nowe sztuczki. Chwilowo nie miał z nią kłopotów. Aktoreczka Marysia też była kiedyś taka. Należało przeczekać etap drugi - przyzwyczajenie do zagranicznych wojaży, samochodu, willi na Mokotowie i strojów, i dotrwać do etapu trzeciego - nudy, zmęczenia starszym o przeszło dwadzieścia lat łysoniem, rozglądania się za młodym bykiem, kaprysów, fochów, histerii i wreszcie - katastrofy. Cały proces zajmie staremu dwa do trzech lat i wtedy będzie mógł przejść na hinduizm, jeżeli dopisze jeszcze zdrowie. (Stawiński 2006: 15)

Właśnie na te słowa weszła Jadźka. Wystawiona na wojenne przeciągi, okutana w swetry i kamizelki, w niczym nie przypominała Galatei z przedwojennych salonów i zagranicznych wojaży. Przyniosła naczynia do nakrycia stołu. Wstałem i ukłoniłem się jej ceremonialnie. Uśmiechnęła się do mnie bez radości. Wojna uczyniła ją znowu służącą, choć na statusie pani domu; ojciec, niegdyś wspaniały czarodziej, zdolny zamienić jej życie w bajkę, zmalał do rozmiarów starzejącego się pana w wyszarzałym szlafroku. Wymagał starań i obsługi w zamian za wikt i mieszkanie. (Stawiński 2006: 93)

I teraz zastałem oboje w kącie, w świetle ich własnej, luksusowej karbidówki, ojca leżącego, ale już wspartego na łokciu, pod szkockim kocem rodem z Edynburga, o wzorze tartanu Wallace, w czarno-czerwoną kratę. Tyle mu zostało z bogactw i luksusu, z uciech całego życia; miejsce w kącie piwnicy i ten leciutki, barwny koc z najprzedniejszej wełny, lśniący czerwoną plamą wśród szarzyzny męki. Podszedłem do nich w miarę swobodnie. Jadźka siedziała przy nim na dziecinnym taborecie, sztywna jak indiańska squaw przy rannym wojowniku i karmiła go łyżką. Teraz dopiero dojrzałem w niej te wszystkie cnoty, które nie mogły się nigdy objawić w ich wesołym życiu przyjęć, pensjonatów, slipingów i gondol: przyrządzanie kaszy, mycie, wycieranie tyłka, cierpliwość, szorstka czułość, wierność i poświęcenie. Prześniwszy złoty sen, Jadźka wróciła do rzeczywistości i żadne zło nie umiało jej złamać. Mają tę siłę wszyscy ci, których dzieciństwo przebiegało w biedzie, strachu i przemożnej chęci przeżycia mimo wszystko. (Stawiński 2006: 143)

- Страсть до чего люблю, когда красиво играют и поют, - подтвердила Ядя. Она переживала первый этап их супружеской жизни, восторгаясь всем, что с ней происходило, и не спускала глаз с волшебника-отца в ожидании все новых и новых чудес. Пока что у него не было с ней трудностей. Актрисочка 
Марыся когда-то тоже была такой. Но затем, после второго этапа, когда она привыкнет к заграничным вояжам, машине, особняку на Мокотове и нарядам, предстоит этап третий: жизнь с лысеющим мужем, который старше ее более чем на двадцать лет, — все это наскучит ей и утомит ее, и она станет оглядываться вокруг в поисках какого-нибудь жеребчика, а потом начнутся капризы, выкрутасы, истерики, что займет от двух до трех лет, и, наконец, наступит катастрофа. Тогда отец сможет перейти в индуизм, если, конечно, ему позволит здоровье. (Ставинский 1981: 363)

Тут как раз вошла Ядя. Напялившая в борьбе с нынешними сквозняками теплый жилет поверх толстого свитера, она ничем не напоминала Галатею довоенных времен, которая развлекалась с отцом в заграничных вояжах. В руках у нее была посуда - Ядя собиралась накрыть на стол. Я встал и церемонно поклонился ей. Она безрадостно улыбнулась в ответ. Война снова сделала ее прислугой, хотя по штату она и была хозяйкой дома. Отец, некогда изумительный чародей, превративший ее жизнь в сказку, теперь стал обыкновенным маленьким человеком, стареющим мужчиной в вылинявшем халате. Он требовал ухода и забот, взамен чего давал еду и жилье. (Ставинский 1981: 445)

Я застал их в этом углу обоих, освещенных собственной роскошной карбидной лампой. Отец полулежал, опираясь на локоть, укрытый шотландским пледом в серо-красную клетку. Это было все, что у него осталось от богатства и роскоши, от всех радостей жизни: место в углу подвала и этот легкий, яркий плед из тончайшей шерсти, который пылал огненным пятном среди серости и страданий. Я подошел к ним, стараясь держаться как можно свободнее. Ядя сидела возле отца на детской табуреточке, неподвижная, как индианка возле раненого воина, и кормила его из ложечки. Лишь теперь обнаружились ее достоинства, которые никогда не могли бы выявиться в их прежней беспечной жизни, заполненной приемами, путешествиями, поездками на машинах, гондолах и в дорогих спальных вагонах: умение приготовить кашу или вымыть больного, а также терпение и отсутствие брезгливости при уходе за ним, суровая нежность, верность и самоотверженность.

Пережив золотой сон, Ядя вернулась в действительность, и уже никакое зло не способно было сломить ее. Этой силой обладают все те, чье детство проходило в нужде, страхе и непреодолимом желании во что бы то ни стало выжить. (Ставинский 1981: 497- 498)

Estamos ante tres pasajes distintos en la novela sobre el mismo personaje cuya figura recibe primero un tratamiento irónico, luego un tratamiento objetivo y en tercer lugar un tratamiento lírico. Tres estilos distintos reflejan la evolución de la actitud que ha ido teniendo el protagonista hacia la última mujer de su padre, vista al comienzo como una mujer interesada, más adelante como una mujer resignada y finalmente como una mujer entregada y sincera. El traductor hace uso de evidencias, del contexto situacional, en otra ocasión es parco desde el punto de vista lingüístico; por último, logra recrear el escenario mediante la elección de un léxico adecuado y el uso de diminutivos, es algo más descriptivo y se ajusta a las imágenes, muy 
expresivas, del original. Como curiosidad, destacar que en la traducción no se ha contemplado el uso del hipocorístico del nombre Jadzia (Jadźka) con el que el narrador-protagonista alude en los dos últimos fragmentos a la esposa de su padre, un detalle no desprovisto de significado ya que denota mayor confianza y afecto en la relación.

Son muchos los pasajes en la novela que muestran la combinación de distintas formas narrativas, a menudo incluso en cadena, y todas ellas de la voz del narradorprotagonista y del propio escritor quien definía esta obra como la más autobiográfica entre todos sus libros. Stawiński es capaz de darle un tratamiento serio a las cosas más cotidianas, aparentemente superficiales y de plantear cuestiones muy serias y dramáticas con sentido del humor. Su dramatismo guarda una compostura, cabe señalar, propia de grandes escritores polacos del siglo XX. La literatura de Tadeusz Borowski, Stanisław Lem, Jerzy Andrzejewski y de otros muchos autores polacos tiene un contenido de lo más serio, desde una experiencia amarga y dolorosa, pero sin desgarro y dramatismo aplastante. El arte del traductor en este sentido radica en su capacidad de abstracción voluntaria: el contenido abrumador debe resultar compatible con un estilo sutil y ligero en su percepción haciéndose eco del espíritu de una generación joven que en circunstancias trágicas deseaba ser feliz, deseaba amar y fue auténtica.

\section{Referencias bibliográficas}

Muñoz Molina, A., Plenilunio. Madrid: Alfaguara 2006.

StAwIŃSKI, J.S., Młodego warszawiaka zapiski z urodzin. Warszawa: Wydawnictwo Trio 2006.

БРАНДЕС, М, Стиль и перевод. Москва: Высшая школа 1998.

Ермонский, А., «О войне, о добре, о любви», еn СТАВИНСКИЙ, Е. С., Избранное. Москва: Художественная литература 1981, 3-8.

Есин, А., Принщипы и приёмы анализа литературного произведения. Москва: Флинта, Наука 2008.

Комиссаров, В., Теория перевода (лингвистические аспекты). Москва: Высшая школа 1990.

СтАВинский, Е. С., 1981. «Записки молодого варшавянина», еn СТАВИНСКИЙ, Е. С., Избранное. Москва: Художественная литература 1981, 353-541.

ФЕдоров, А., Язык и стиль художественного произведения. Москва: Государственное издательство художественной литературы 1963. 